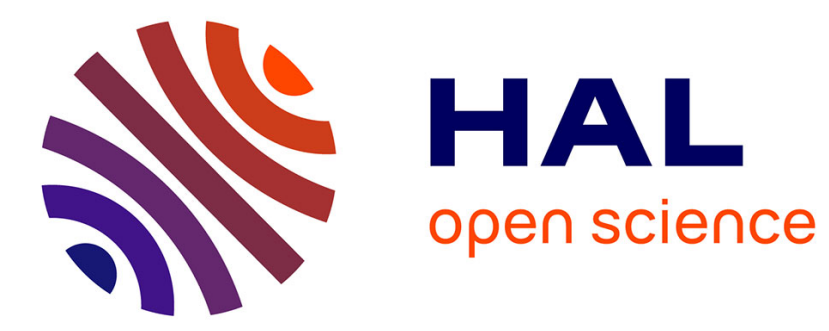

\title{
Synthesis and sintering of nano-sized BaSnO3 powders containing BaGeO3
}

\author{
Roberto Köferstein, Lothar Jäger, Mandy Zenkner, Francisco Javier \\ García-García, Stefan G Ebbinghaus
}

\section{- To cite this version:}

Roberto Köferstein, Lothar Jäger, Mandy Zenkner, Francisco Javier García-García, Stefan G Ebbinghaus. Synthesis and sintering of nano-sized $\mathrm{BaSnO} 3$ powders containing BaGeO3. Journal of Materials Science, 2010, 45 (14), pp.3784-3790. 10.1007/s10853-010-4432-5 . hal-02004736

\section{HAL Id: hal-02004736 \\ https://hal.science/hal-02004736}

Submitted on 2 Feb 2019

HAL is a multi-disciplinary open access archive for the deposit and dissemination of scientific research documents, whether they are published or not. The documents may come from teaching and research institutions in France or abroad, or from public or private research centers.
L'archive ouverte pluridisciplinaire $\mathbf{H A L}$, est destinée au dépôt et à la diffusion de documents scientifiques de niveau recherche, publiés ou non, émanant des établissements d'enseignement et de recherche français ou étrangers, des laboratoires publics ou privés. 


\section{Journal of Material Science (2010) 45:3784-3790 \\ (DOI 10.1007/s10853-010-4432-5)}

\section{http://link.springer.com/article/10.1007\%2Fs10853-010-4432-5}

\section{Synthesis and sintering of nano-sized $\mathrm{BaSnO}_{3}$ powders containing $\mathrm{BaGeO}_{3}$}

Roberto Köferstein $^{\mathrm{a}, *}$, Lothar Jäger ${ }^{\mathrm{a}}$, Mandy Zenkner ${ }^{\mathrm{a}}$, Francisco Javier García-García ${ }^{\mathrm{b}}$, Stefan G. Ebbinghaus ${ }^{\mathrm{a}}$

a Institut für Chemie, Anorganische Chemie, Martin-Luther-Universität Halle-Wittenberg, Kurt-Mothes Strasse 2, D-06120 Halle, Germany

${ }^{b}$ Lehrstuhl für Festkörperchemie, Institut für Physik, Universität Augsburg, Universitätsstrasse 1, D-86159 Augsburg, Germany

* Corresponding author. Tel.: +49-345-5525630; Fax: +49-345-5527028.

E-mail address: roberto.koeferstein@ chemie.uni-halle.de

Abstract. The formation of solid solutions of the type $\left[\mathrm{Ba}\left(\mathrm{HOC}_{2} \mathrm{H}_{4} \mathrm{OH}\right)_{4}\right]\left[\mathrm{Sn}_{1-x} \mathrm{Ge}_{x}\left(\mathrm{OC}_{2} \mathrm{H}_{4} \mathrm{O}\right)_{3}\right]$ as $\mathrm{BaSn}_{1-x} / \mathrm{Ge}_{x} \mathrm{O}_{3}$ precursor and the phase evolution during its thermal decomposition are described in this paper. The 1,2-ethanediolato complexes can be decomposed to nano-sized $\mathrm{BaSn}_{1-x} / \mathrm{Ge}_{x} \mathrm{O}_{3}$ preceramic powders. Samples with $x=0.05$ consist of only a $\mathrm{Ba}(\mathrm{Sn}, \mathrm{Ge}) \mathrm{O}_{3}$ phase, whereas powders with $x=0.15$ and 0.25 show diffraction patterns of both the $\mathrm{Ba}(\mathrm{Sn}, \mathrm{Ge}) \mathrm{O}_{3}$ and $\mathrm{BaGeO}_{3}$ phase. The sintering behaviour was investigated on powders with a $\mathrm{BaGeO}_{3}$ content of 5 and $15 \mathrm{~mol} \%$. These powders show a 
specific surface area of $15.4-15.9 \mathrm{~m}^{2} / \mathrm{g}$ and were obtained from calcination above $800{ }^{\circ} \mathrm{C}$. The addition of $\mathrm{BaGeO}_{3}$ reduced the sintering temperature of the ceramics drastically. $\mathrm{BaSn}_{0.95} \mathrm{Ge}_{0.05} \mathrm{O}_{3}$ ceramics with a relative density of at least $90 \%$ can be obtained by sintering at $1150{ }^{\circ} \mathrm{C}$ for $1 \mathrm{~h}$. The ceramic bodies reveal a fine microstructure with cubical-shaped grains between $0.25-0.6 \mu \mathrm{m}$. For dense ceramics the sintering temperature could be reduced down to $1090{ }^{\circ} \mathrm{C}$, when the soaking time was extended up to $10 \mathrm{~h}$.

Keywords: $\mathrm{BaSnO}_{3} ; \mathrm{BaGeO}_{3}$; precursor; thermal decomposition; ceramic; sintering

\section{Introduction}

Pure and doped barium stannate $\left(\mathrm{BaSnO}_{3}\right)$ as well as its solid solutions (e.g. $\mathrm{BaTi}_{1-x} \mathrm{Sn}_{x} \mathrm{O}_{3}$ ) have found important applications in materials science and technology due to its dielectric properties, semiconducting behaviour and high thermal stability $[1,2,3]$. Because of these characteristic properties, $\mathrm{BaSnO}_{3}$ based ceramics are becoming more and more important in materials technology. For example, $\mathrm{BaSnO}_{3}$ can be used to prepare thermally stable capacitors and to fabricate ceramic boundary layer capacitors $[4,5,6,7,8,9,10,11,12]$. Furthermore, $\mathrm{BaSnO}_{3}$ can be also used as a functional material for semiconductor gas sensors and photocatalytic applications $[13,14,15,16,17,18,19,20]$. $\mathrm{BaSnO}_{3}$ crystallises in the perovskitetype structure and has a band gap of $3.4 \mathrm{eV}$ [21]. Apart from the mixed-oxide method, which results in coarse-grained powders, some chemical syntheses have been developed to obtain fine-grained $\mathrm{BaSnO}_{3}$ powders. Hydrothermal and sol-gel $[22,23,24,25]$ synthesis as well as precursor complex, coprecipitation- and polymerised complex methods [26,27,28,29] are suitable to obtain fine-grained $\mathrm{BaSnO}_{3}$ powders. Compacts on the basis of $\mathrm{BaSnO}_{3}$ generally reveal only a moderate densification behaviour [5,30,31,32,33,34,35,36,37]. Therefore, such ceramic bodies need high sintering temperatures or very long soaking times. In order to 
produce capacitor components based on $\mathrm{BaSnO}_{3}$, dense (i.e. almost pore free) material bodies are required, because pores would act as a sink to the electrical charge carriers and would be the source of poor grain-to-grain connectivity and significant dielectric losses $[34,35,38,39,40,41,42]$. The densification behaviour can be improved and thus the sintering temperature can be reduced using fine-grained powders [30] or sintering aids [43,44]. Kumar and Choudhary [45] sintered coarse-grained $\mathrm{BaSnO}_{3}$ adding $\mathrm{BaSiO}_{3}$, while Wang et al. [46] used $\mathrm{SiO}_{2}$ as a sintering aid for $\mathrm{BaSnO}_{3}$. Recently, we have investigated the effect of $\mathrm{BaGeO}_{3}$ on the sintering properties and microstructures of both $\mathrm{BaSnO}_{3}$ ceramic bodies prepared by the classical mixed-oxide method [47] and $\mathrm{BaTiO}_{3}$-based ceramics [48].

The present study deals with the preparation of a $\mathrm{Ba}(\mathrm{Sn}, \mathrm{Ge})-1$,2-ethanediolato complex precursor, including a sintering aid component, which can be decomposed to nano-sized $\mathrm{BaSn}_{1-\mathrm{x}} / \mathrm{Ge}_{\mathrm{x}} \mathrm{O}_{3}$ powders. In this precursor the components are evenly distributed on a molecular level, which leads to a more homogeneous distribution of the sintering aid in the resulting ceramic bodies. Additionally, phase evolution, the sintering behaviour of $\mathrm{BaSn}_{1-}$ ${ }_{\mathrm{x}} / \mathrm{Ge}_{\mathrm{x}} \mathrm{O}_{3}$ compacts as well as the microstructures of resulting ceramic bodies have been investigated.

\section{Experimental}

\subsection{Material preparation}

$\left[\mathrm{Ba}\left(\mathrm{HOC}_{2} \mathrm{H}_{4} \mathrm{OH}\right)_{4}\right]\left[\mathrm{Sn}_{1-x} \mathrm{Ge}_{x}\left(\mathrm{OC}_{2} \mathrm{H}_{4} \mathrm{O}\right)_{3}\right]$ precursor complexes were prepared analogously to the preparation of $\left[\mathrm{Ba}\left(\mathrm{HOC}_{2} \mathrm{H}_{4} \mathrm{OH}\right)_{4}\right]\left[\mathrm{Sn}\left(\mathrm{OC}_{2} \mathrm{H}_{4} \mathrm{O}\right)_{3}\right]$ [30]. Ice-cold water $(800 \mathrm{~mL})$ was slowly added to fresh distilled $\mathrm{SnCl}_{4}(0.10-x$ mol; p.a., Laborchemie Apolda) and then a concentrated ammonia solution was added to adjust a $\mathrm{pH}$ value of $7-7.5$. The precipitate was slowly filtered off and washed with water until the filtrate was almost free from $\mathrm{Cl}^{-}$ions. A suspension of this wet precipitate $\left(\mathrm{SnO}_{2} \cdot n \mathrm{H}_{2} \mathrm{O}\right)$ with $\mathrm{Ba}(\mathrm{OH})_{2} \cdot 8 \mathrm{H}_{2} \mathrm{O}(0.10-x$ mol; puriss. p.a., Fluka) and $800 \mathrm{~mL} \mathrm{1,2-ethanediol} \mathrm{was} \mathrm{stirred} \mathrm{overnight} \mathrm{at} \mathrm{room} \mathrm{temperature} \mathrm{in} \mathrm{an} \mathrm{argon}$ 
atmosphere. Thereafter, the suspension was heated at about $130{ }^{\circ} \mathrm{C}$ to remove water. Afterwards $\mathrm{Ge}\left(\mathrm{OC}_{2} \mathrm{H}_{5}\right)_{4}(x \mathrm{~mol}$, Alfa Aesar $\mathrm{GmbH} \& \mathrm{Co} K G)$ and $x$ mol Ba(OH$)_{2} \cdot 8 \mathrm{H}_{2} \mathrm{O}$ were added. The reaction mixture was heated at $120-130{ }^{\circ} \mathrm{C}$ for $8 \mathrm{~h}$. About $2 / 3$ of the solvent was removed under reduced pressure at about $80{ }^{\circ} \mathrm{C}$. The reaction mixture was then cooled to room temperature and diluted with propan-2-ol. The white, crystalline precipitate of $\left[\mathrm{Ba}\left(\mathrm{HOC}_{2} \mathrm{H}_{4} \mathrm{OH}\right)_{4}\right]\left[\mathrm{Sn}_{1-x} \mathrm{Ge}_{x}\left(\mathrm{OC}_{2} \mathrm{H}_{4} \mathrm{O}\right)_{3}\right]$ was filtered, washed with acetone and dried at room temperature in vacuum.

For the shrinkage and sintering studies the precursor complexes with $x=0.05$ and 0.15 were calcined in static air at 850 and $860{ }^{\circ} \mathrm{C}$ by a heating rate controlled thermal treatment, as described below. The calcined powders were milled with $\mathrm{ZrO}_{2}$-balls in propan-2-ol for $2 \mathrm{~h}$ $\left(\mathrm{m}_{\text {powder }}: \mathrm{m}_{\text {balls }}=1: 4\right)$. After filtering and drying, the powders were mixed with 5 mass $\%$ of a saturated aqueous solution of polyvinyl alcohol (PVA) as a pressing aid, then the powders were pressed to discs with a green density of about $2.8-3.0 \mathrm{~g} / \mathrm{cm}^{3}$.

\subsection{Characterization}

X-ray powder diffraction (XRD) patterns were recorded on a STOE STADI MP diffractometer at $20{ }^{\circ} \mathrm{C}$ using $\mathrm{Co}-\mathrm{K} \alpha_{1}$ radiation. Dilatometric (shrinkage) investigations were performed in a flowing synthetic air atmosphere $(50 \mathrm{ml} / \mathrm{min})$ in a TMA 92-16.18 unit from Setaram. The specific surface area was determined using nitrogen three-point BET (Nova 1000, Quantachrome Corporation). The equivalent BET particle diameter was calculated assuming the powder particles were spherical or cubic in shape [49]. Crystallite sizes were determined with the software suite WinXPOW [50] by XRD line broadening using the Scherrer equation [51] and the integral peak breadth. Scanning electron microscope images were recorded with a Philips XL30 ESEM (Environmental Scanning Electron Microscope) and transmission electron microscope images were recorded with a Jeol JEM 2100F. 


\section{Results and discussion}

\subsection{Solid solutions of the type $\left[\mathrm{Ba}\left(\mathrm{HOC}_{2} \mathrm{H}_{4} \mathrm{OH}\right)_{4}\right]\left[\mathrm{Sn}_{1-x} \mathrm{Ge}_{x}\left(\mathrm{OC}_{2} \mathrm{H}_{4} \mathrm{O}\right)_{3}\right]$}

The non-isotypic 1,2-ethanediolato complexes $\left[\mathrm{Ba}\left(\mathrm{HOC}_{2} \mathrm{H}_{4} \mathrm{OH}\right)_{4}\right]\left[\mathrm{Sn}\left(\mathrm{OC}_{2} \mathrm{H}_{4} \mathrm{O}\right)_{3}\right]$ (1) and $\left[\mathrm{Ba}\left(\mathrm{HOC}_{2} \mathrm{H}_{4} \mathrm{OH}\right)_{2} \mathrm{Ge}\left(\mathrm{OC}_{2} \mathrm{H}_{4} \mathrm{O}\right)_{3}\right]$ (2) can be used as precursors for fine-grained $\mathrm{BaSnO}_{3}$ and $\mathrm{BaGeO}_{3}$ powders [30,52,53]. We have prepared mixed precursor complexes of $\mathbf{1}$ and $\mathbf{2}$ up to a germanium content of $25 \mathrm{~mol} \%$. Since the XRD patterns of the $\mathrm{Ba}(\mathrm{Sn}, \mathrm{Ge})$-precursor complexes (Fig. 1b-d) show only the reflection pattern of complex 1 (Fig. 1a) it can be concluded that each precursor consists of a single phase indicating the formation of solid solutions of the type $\left[\mathrm{Ba}\left(\mathrm{HOC}_{2} \mathrm{H}_{4} \mathrm{OH}\right)_{4}\right]\left[\mathrm{Sn}_{1-x} \mathrm{Ge}_{x}\left(\mathrm{OC}_{2} \mathrm{H}_{4} \mathrm{O}\right)_{3}\right]$ up to $x=0.25$. Furthermore, the insertion of $\mathrm{Ge}^{4+}$ into the crystal structure of $\mathbf{1}$ is connected to a decrease in unit cell volume (inset in Fig. 1).

Fig. 2 represents XRD patterns of $\left[\mathrm{Ba}\left(\mathrm{HOC}_{2} \mathrm{H}_{4} \mathrm{OH}\right)_{4}\right]\left[\mathrm{Sn}_{0.75} \mathrm{Ge}_{0.25}\left(\mathrm{OC}_{2} \mathrm{H}_{4} \mathrm{O}\right)_{3}\right](\mathbf{2 5}$, the number represents the germanium content) after different calcination steps in static air (heating rate 10 ${ }^{\circ} \mathrm{C} / \mathrm{min}$ ). Analogous to the calcination of the complexes $\mathbf{1}$ and 2, precursor $\mathbf{2 5}$ disintegrated into $\mathrm{BaCO}_{3}, \mathrm{SnO}_{2}$ and $\mathrm{GeO}_{2}$ at $500{ }^{\circ} \mathrm{C}$. The XRD pattern (Fig. 2a) clearly shows reflections of orthorhombic $\mathrm{BaCO}_{3}$ and tetragonal $\mathrm{GeO}_{2}$ [54]. The reflection at $2 \theta=31.0^{\circ}$ represents tetragonal $\mathrm{SnO}_{2}$ and possibly hexagonal $\mathrm{GeO}_{2}$ [54]. Heating at $650{ }^{\circ} \mathrm{C}$ (Fig. 2b) leads to a reduction of the intensities of reflections representing $\mathrm{SnO}_{2}$ and $\mathrm{GeO}_{2}$. The broad reflection around $2 \theta=35.5^{\circ}$ indicates the evolution of $\mathrm{BaSnO}_{3}$ [54]. Calcination at $700{ }^{\circ} \mathrm{C}$ for $1 \mathrm{~h}$ results in strong reflections of $\mathrm{BaSnO}_{3}$, whereas the reflection for tetragonal $\mathrm{GeO}_{2}$ disappears (Fig. 2c). XRD pattern after a heat treatment at $900{ }^{\circ} \mathrm{C}$ reveals the formation of orthorhombic $\mathrm{BaGeO}_{3}$ (not shown) and at $1000{ }^{\circ} \mathrm{C}$ we clearly observe reflections of $\mathrm{BaSnO}_{3}$ and orthorhombic $\mathrm{BaGeO}_{3}$ (Fig. 2d). The small amount of $\mathrm{BaCO}_{3}$ completely vanished above $1000{ }^{\circ} \mathrm{C}$ (Fig. 2e). In ref. [47] it was observed a partial solid solubility of $\mathrm{BaGeO}_{3}$ in $\mathrm{BaSnO}_{3}$ of the order of 6-7 mol\%. Therefore, the reflections of $\mathrm{BaSnO}_{3}$ represent the perovskite phase $\mathrm{Ba}(\mathrm{Sn}, \mathrm{Ge}) \mathrm{O}_{3}$. 


\subsection{Shrinkage and sintering behaviour}

Preceramic powders with $\mathrm{BaGeO}_{3}$ contents of $5 \mathrm{~mol} \%$ (5) and $15 \mathrm{~mol} \%$ (15) were used for investigations of the sintering behaviour. Powders $\mathbf{5}$ and $\mathbf{1 5}$ were obtained after calcination of $\left[\mathrm{Ba}\left(\mathrm{HOC}_{2} \mathrm{H}_{4} \mathrm{OH}\right)_{4}\right]\left[\mathrm{Sn}_{0.95} \mathrm{Ge}_{0.05}\left(\mathrm{OC}_{2} \mathrm{H}_{4} \mathrm{O}\right)_{3}\right]$ and $\left[\mathrm{Ba}\left(\mathrm{HOC}_{2} \mathrm{H}_{4} \mathrm{OH}\right)_{4}\right]\left[\mathrm{Sn}_{0.85} \mathrm{Ge}_{0.15}\left(\mathrm{OC}_{2} \mathrm{H}_{4} \mathrm{O}\right)_{3}\right]$, respectively. The calcination procedure of $\mathbf{5}$ was as follow: heating at $10{ }^{\circ} \mathrm{C} / \mathrm{min}$ to $500{ }^{\circ} \mathrm{C}$, then slow heating at $1{ }^{\circ} \mathrm{C} / \mathrm{min}$ to $850{ }^{\circ} \mathrm{C}$, soaking for $3 \mathrm{~h}$ and cooling at $3{ }^{\circ} \mathrm{C} / \mathrm{min}$. Powder $\mathbf{1 5}$ was obtained in nearly the same manner, however, the precursor was heated up to $860{ }^{\circ} \mathrm{C}$ for 10 h. As seen in Fig. $7 b$, sample 5 consists of a $\mathrm{Ba}(\mathrm{Sn}, \mathrm{Ge}) \mathrm{O}_{3}$ perovskite phase and a small amount of $\mathrm{BaCO}_{3}$. Whereas, powder 15 reveals reflections of a $\mathrm{Ba}(\mathrm{Sn}, \mathrm{Ge}) \mathrm{O}_{3}$ phase, small amounts of $\mathrm{BaCO}_{3}$ and $\mathrm{SnO}_{2}$ (Fig. 7a). The specific surface area (BET) of these powders was determined as $15.4 \mathrm{~m}^{2} / \mathrm{g}(\mathbf{5})$ and $15.9 \mathrm{~m}^{2} / \mathrm{g}(\mathbf{1 5})$, respectively. The equivalent particle size from these BET data was calculated as $55 \mathrm{~nm}$, which can be considered as an average size of the primary particles [55]. Crystallite-size measurements by XRD line broadening [51] of the $\mathrm{Ba}(\mathrm{Sn}, \mathrm{Ge}) \mathrm{O}_{3}$ reflexions reveal lower values of about $\mathrm{d}_{\text {crys. }}=22 \mathrm{~nm}(\mathbf{5})$ and $24 \mathrm{~nm}(\mathbf{1 5})$, respectively. Discrepancies between the crystallite-/particle size estimated by the XRD line broadening and the specific surface area were reported and explained elsewhere [43]. The decomposition of the precursor complexes leads to the development of an internal surface in the powder (closely joined crystallites), which is unavailable for nitrogen adsorption. Analogous discrepancies between the particle-/crystallite-size estimated by the XRD line broadening and the specific surface area were also observed in studies of $\mathrm{ThO}_{2}$ and $\mathrm{ZrO}_{2}$ [49,56]. TEM images of powder 5 are seen in Fig. 3. The theoretical bulk densities of the resulting ceramic bodies were calculated as $7.12 \mathrm{~g} / \mathrm{cm}^{3}(\mathbf{5})$ and $6.85 \mathrm{~g} / \mathrm{cm}^{3}$ (15) [57].

The non-isothermal shrinkage behaviour (dilatometry) of powders $\mathbf{5}$ and $\mathbf{1 5}$ can be seen in Fig. 4. Both powders reveal the beginning of shrinkage at about $1000{ }^{\circ} \mathrm{C}$, however, a significant shrinkage occurs above $1100{ }^{\circ} \mathrm{C}(5)$ and $1000{ }^{\circ} \mathrm{C}(\mathbf{1 5})$, respectively. Powder 15 
begins to shrink at lower temperatures than powder $\mathbf{5}$. On the other hand, powder $\mathbf{5}$ shows a very fast shrinkage process with a shrinkage rate maximum of $-7.9 \% / \mathrm{min}$ at $1240{ }^{\circ} \mathrm{C}$. The intensity of the shrinkage process of sample $\mathbf{1 5}$ is lower. We observe one rate maximum at $1106{ }^{\circ} \mathrm{C}(-2.5 \% / \mathrm{min})$ and another broad one at $1242{ }^{\circ} \mathrm{C}(-1.5 \% / \mathrm{min})$. The small difference of the whole shrinkage of both samples is mainly caused by different green densities of the compacts.

The final bulk densities of ceramic bodies (measured from their weight and dimensions) of $\mathbf{5}$ and 15 after conventional isothermal sintering for 1 and $10 \mathrm{~h}$ (heating rate $10{ }^{\circ} \mathrm{C} / \mathrm{min}$ ) are shown in Fig. 5. Dense ceramics (rel. density $\geq 90 \%$ ) can be obtained after sintering at a minimum temperature of $1150{ }^{\circ} \mathrm{C}$ for $1 \mathrm{~h}(\mathbf{5})$, which is more than $400 \mathrm{~K}$ lower than for nano$\mathrm{BaSnO}_{3}$ without any additives [30] (Fig. 5a). The ceramic body reveals cubic grains in a small range between $0.25-0.6 \mu \mathrm{m}$ (Fig. 6a). A higher $\mathrm{BaGeO}_{3}$ content of 15 mol\% (15) needs sintering temperatures considerable above $1150{ }^{\circ} \mathrm{C}$ to form dense ceramic bodies. The relative densities of samples $\mathbf{5}$ and $\mathbf{1 5}$ do not differ significantly above a sintering temperature of 1200 ${ }^{\circ} \mathrm{C}$. Up to $1300{ }^{\circ} \mathrm{C}$ ceramic bodies with relative densities of $98-99 \%$ can be obtained (Fig. 5a). The final microstructures of ceramics of 5 after sintering of $1 \mathrm{~h}$ at $1200{ }^{\circ} \mathrm{C}$ show cubic or cuboid-like grains between about $0.25-2 \mu \mathrm{m}$, at $1250{ }^{\circ} \mathrm{C}$ a bi-modal grain-size distribution with grains between $0.5-5 \mu \mathrm{m}$ (Fig. 6b), and at $1300{ }^{\circ} \mathrm{C}$ we found grains between $1.9-12 \mu \mathrm{m}$ (Fig. 6c). The microstructures exhibit that small grains have a cubical- or cuboid-like shape, whereas larger grains have an increasingly irregular shape.

A prolonged soaking time of $10 \mathrm{~h}$ decreases the minimum sintering temperature for dense ceramic bodies down to $1090{ }^{\circ} \mathrm{C}(\mathbf{5})$ with grains in the range between $0.35-1 \mu \mathrm{m}$ (Fig. $5 \mathrm{~b}$, 6d). A higher sintering temperature of $1150{ }^{\circ} \mathrm{C}(10 \mathrm{~h})$ leads to a grain growth with irregular grains between 1.9 and $21 \mu \mathrm{m}$ (Fig. 6e). Sample 15 requires temperatures above $1120{ }^{\circ} \mathrm{C}$ to reach relative densities of $\geq 90 \%$ (Fig. 5b). Compared to the microstructure of ceramics 
sintered for $1 \mathrm{~h}$, we found more grains with an irregular shape after the prolonged sintering time. It can be seen that the absolute densities of ceramic bodies of $\mathbf{1 5}$ are almost always lower than of bodies of $\mathbf{5}$. As mentioned above, sample $\mathbf{1 5}$ has only a maximal reachable density of $6.89 \mathrm{~g} / \mathrm{cm}^{3}$, whereas sample 5 can achieve a maximum density of $7.12 \mathrm{~g} / \mathrm{cm}^{3}$.

For comparison, $\mathrm{BaSnO}_{3}$ compacts prepared by a precursor route without any additive show only very moderate sintering behaviour. Sintering temperatures above $1550{ }^{\circ} \mathrm{C}$ are necessary to reach a relative density of $90 \%[30]$.

Ceramic bodies of $\mathbf{5}$ exclusively show reflections of the $\mathrm{BaSnO}_{3}$ phase; no other crystalline phase can be detected (Fig. 7c,d). Consequently, ceramic bodies of 5 consist of a solid solution between $\mathrm{BaSnO}_{3}$ and $\mathrm{BaGeO}_{3}\left(\mathrm{BaSn}_{0.95} \mathrm{Ge}_{0.05} \mathrm{O}_{3}\right)$ [47]. By contrast, powder patterns of ceramics of 15 clearly indicate reflections of both the $\mathrm{Ba}(\mathrm{Sn}, \mathrm{Ge}) \mathrm{O}_{3}$ phase and the orthorhombic $\mathrm{BaGeO}_{3}$ phase (Fig. 7e-g).

The isothermal sintering results clearly show that dense ceramic bodies can be obtained at sintering temperatures considerable below $1250{ }^{\circ} \mathrm{C}$. As reported in ref. [47] $\mathrm{BaSnO}_{3}$ and $\mathrm{BaGeO}_{3}$ form a liquid phase at $1270{ }^{\circ} \mathrm{C}$. As mentioned above, the non-isothermal dilatometric measurements (Fig. 4) show shrinkage maxima at temperatures $<1270{ }^{\circ} \mathrm{C}$ and the maximum shrinkage rates $(\gg 0.1 \% / \mathrm{min})$ suggest that the shrinkage is dominated by sliding processes $[58,59]$. That means, the formation of a liquid phase is not essential to form dense ceramic bodies and the densification process can be described as a solid-state sintering process. Consequently, the sintering additive $\mathrm{BaGeO}_{3}$ does not act as a liquid phase former, primarily. $\mathrm{BaGeO}_{3}$ as well as the small grain size of the preceramic powders $(\mathbf{5}, \mathbf{1 5})$ improve the sliding processes [60]. Such sliding processes are caused by defect-rich and amorphous (glass-like) contact boundaries, respectively $[61,62,63]$. Dror et al. [64] could show that these sliding processes (rearrangements) correlate also with the high amount of grain boundaries in nanopowders. They regarded the grain boundaries as amorphous areas surrounding crystalline cores, which promotes the sliding processes. 


\section{Conclusion}

The sintering temperature of $\mathrm{BaSnO}_{3}$ or $\mathrm{BaSnO}_{3}$-based ceramics can be drastically lowered using both nano-sizes powders and the sintering additive $\mathrm{BaGeO}_{3}$. To combine both effects we synthesized $\left[\mathrm{Ba}\left(\mathrm{HOC}_{2} \mathrm{H}_{4} \mathrm{OH}\right)_{4}\right]\left[\mathrm{Sn}_{1-x} \mathrm{Ge}_{x}\left(\mathrm{OC}_{2} \mathrm{H}_{4} \mathrm{O}\right)_{3}\right](x=0.05$ (5), $0.15(\mathbf{1 5}), 0.25(\mathbf{2 5}))$ precursor complexes, which can be decomposed to nano-sized $\mathrm{BaSnO}_{3}$ powders containing $\mathrm{BaGeO}_{3}$. The decomposition of precursor 5 finally leads to a single-phase powder indicating a solid solution between $\mathrm{BaSnO}_{3}$ and $\mathrm{BaGeO}_{3}$. On the other hand heat treatment of precursor 15 results in a powder and ceramic bodies containing both the $\mathrm{Ba}(\mathrm{Sn}, \mathrm{Ge}) \mathrm{O}_{3}$ perovskite phase and orthorhombic $\mathrm{BaGeO}_{3}$. Isothermal sintering experiments of resulting compacts show a drastically reduction of the sintering temperature. Dense ceramic bodies of $\mathbf{5}$ can be obtained after sintering at $1150{ }^{\circ} \mathrm{C}$ for $1 \mathrm{~h}$ or at $1090{ }^{\circ} \mathrm{C}$ for $10 \mathrm{~h}$, respectively. At these low sintering temperatures the ceramics have cubical-shaped grains between $0.25-0.6 \mu \mathrm{m}$ and $0.35-1 \mu \mathrm{m}$, respectively.

\section{Acknowledgements}

Financial support by the Federal State Saxony-Anhalt (Cluster of Excellence "Nanostructured Materials") is gratefully acknowledged. 


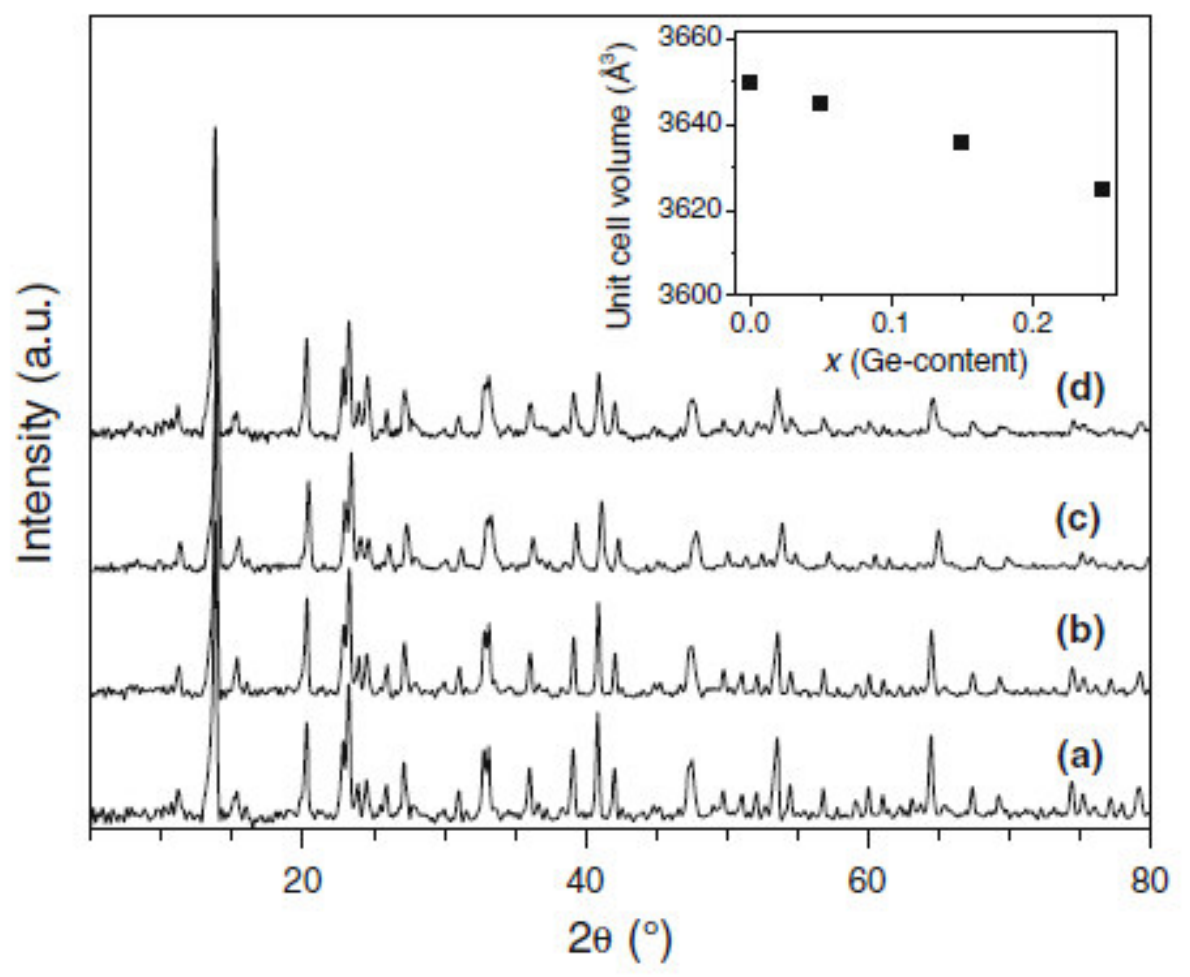

Fig. 1 XRD patterns of selected precursors. (a) $\left[\mathrm{Ba}\left(\mathrm{HOC}_{2} \mathrm{H}_{4} \mathrm{OH}\right)_{4}\right]$ $\left[\mathrm{Sn}\left(\mathrm{OC}_{2} \mathrm{H}_{4} \mathrm{O}\right)_{3}\right](1),(b-d)\left[\mathrm{Ba}\left(\mathrm{HOC}_{2} \mathrm{H}_{4} \mathrm{OH}\right)_{4}\right]\left[\mathrm{Sn}_{1-x} \mathrm{Ge}_{x}\left(\mathrm{OC}_{2} \mathrm{H}_{4} \mathrm{O}\right)_{3}\right]$, (b) $x=0.05$ (5); (c) $x=0.15$ (15); (d) $x=0.25$ (25). The inset shows the relationship between the volume of the unit cell and the germanium content $(x)$ of these complexes 


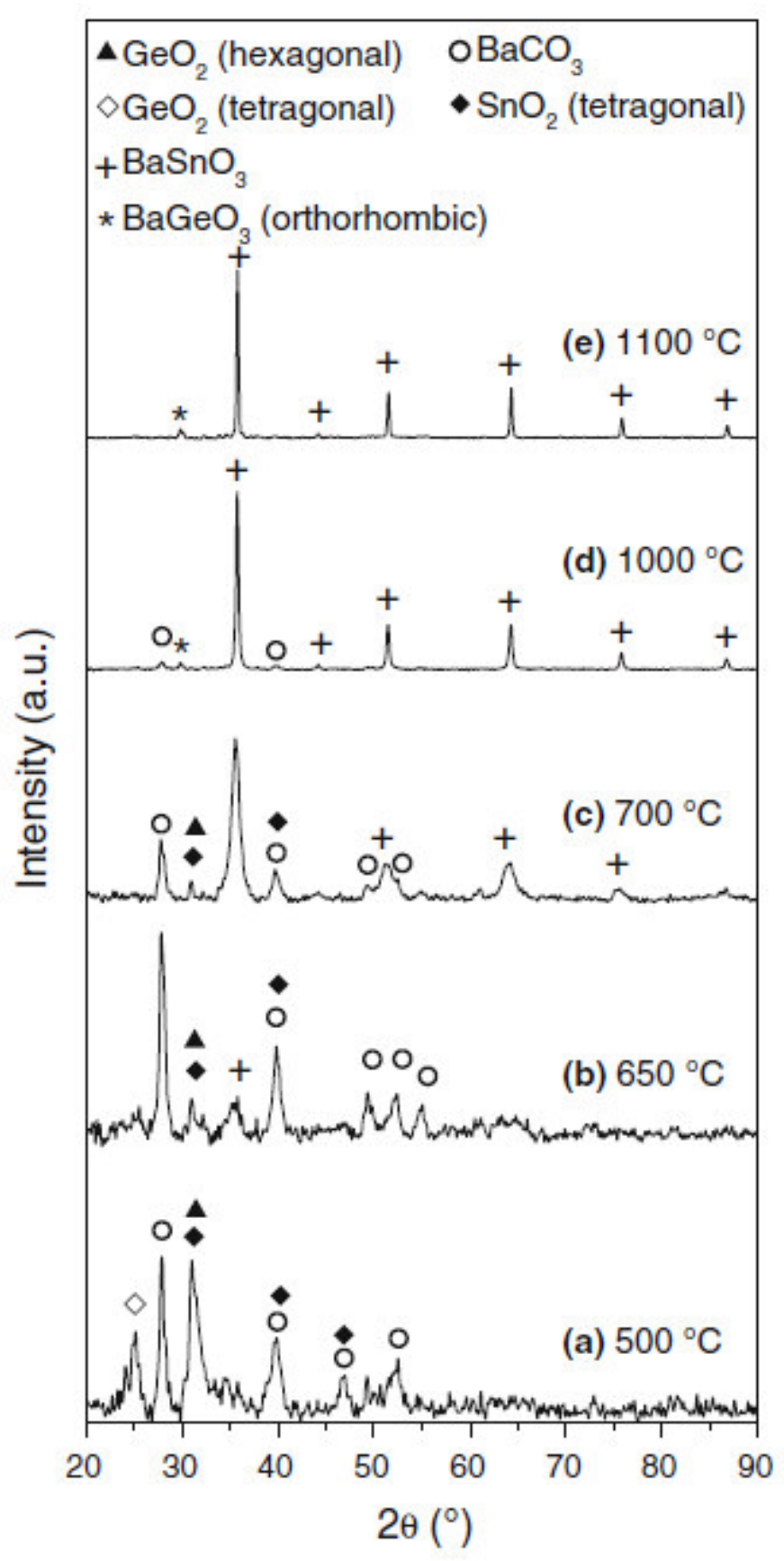

Fig. 2 XRD patterns of the $\left[\mathrm{Ba}\left(\mathrm{HOC}_{2} \mathrm{H}_{4} \mathrm{OH}\right)_{4}\right]\left[\mathrm{Sn}_{0.75} \mathrm{Ge}_{0.25}\left(\mathrm{OC}_{2} \mathrm{H}_{4} \mathrm{O}\right)_{3}\right]$ precursor (25) decomposed at various calcination temperatures (soaking time $1 \mathrm{~h}$, heating rate $10^{\circ} \mathrm{C} / \mathrm{min}$ ) 

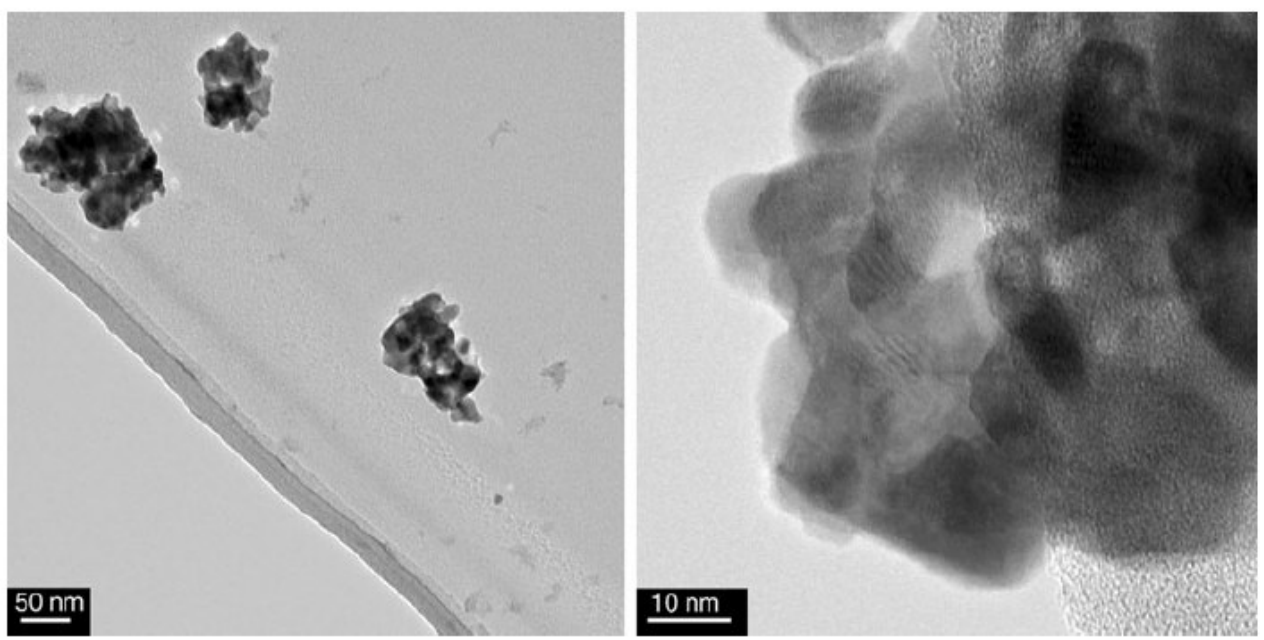

Fig. 3 TEM images of powder 5

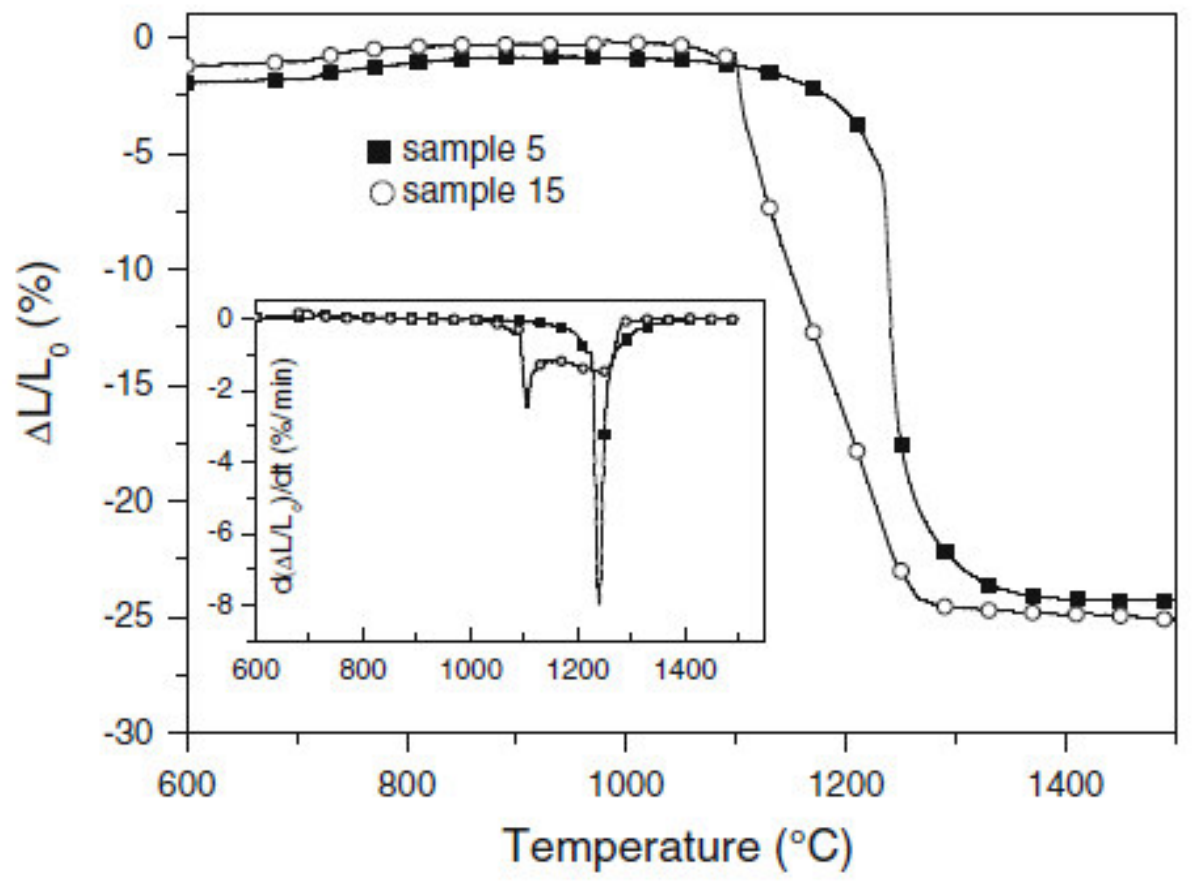

Fig. 4 Non-isothermal dilatometric measurements in air of green bodies of 5 and 15 (heating rate $10{ }^{\circ} \mathrm{C} / \mathrm{min}$ ). The inset shows the relative shrinkage rates of these samples 

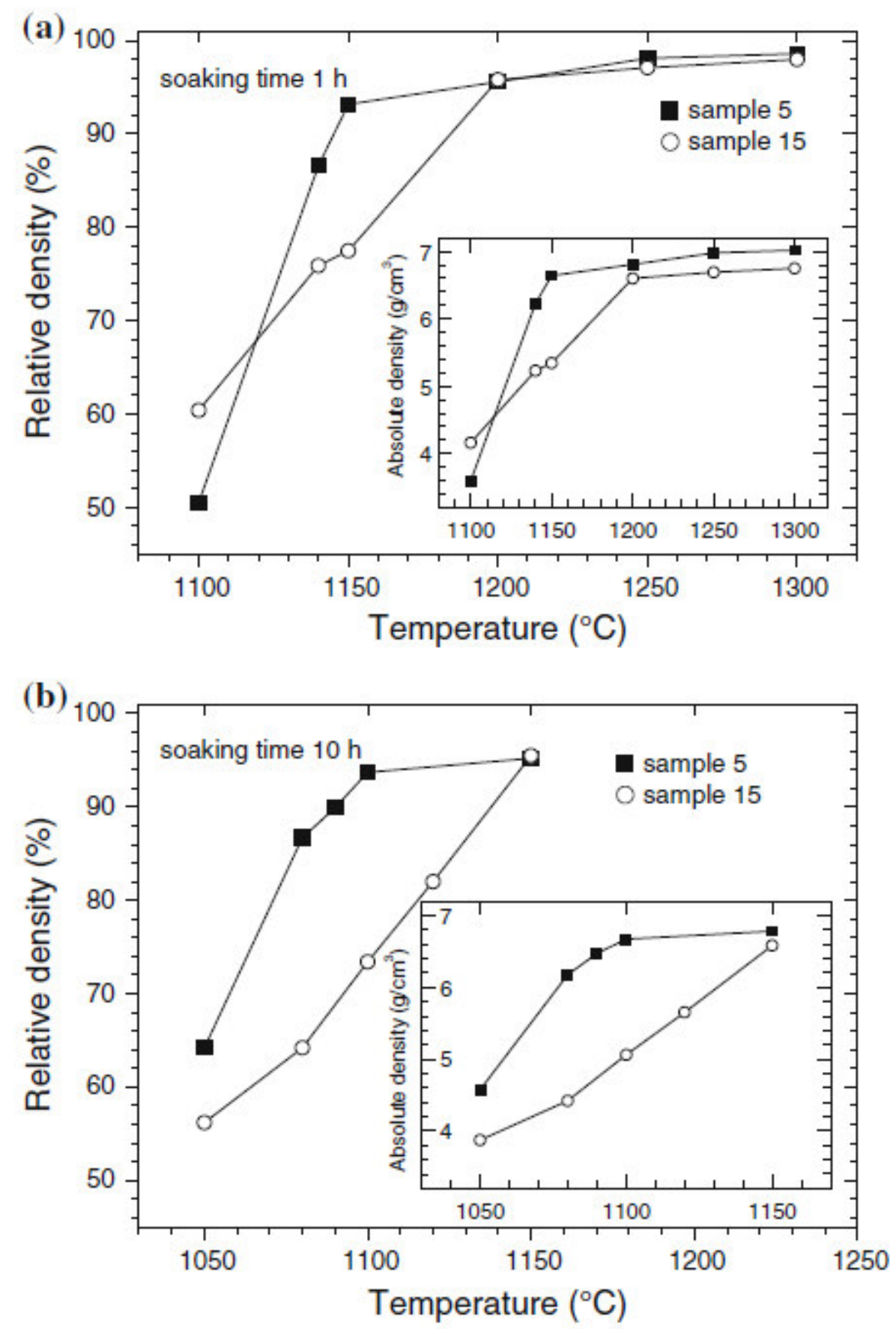

Fig. 5 Evolution of the final densities of some ceramic bodies of $\mathbf{5}$ and 15 after an isothermal sintering process of $\mathbf{a ~} 1 \mathrm{~h}$ and $\mathbf{b ~} 10 \mathrm{~h}$ (rate $10{ }^{\circ} \mathrm{C} / \mathrm{min}$ ) 

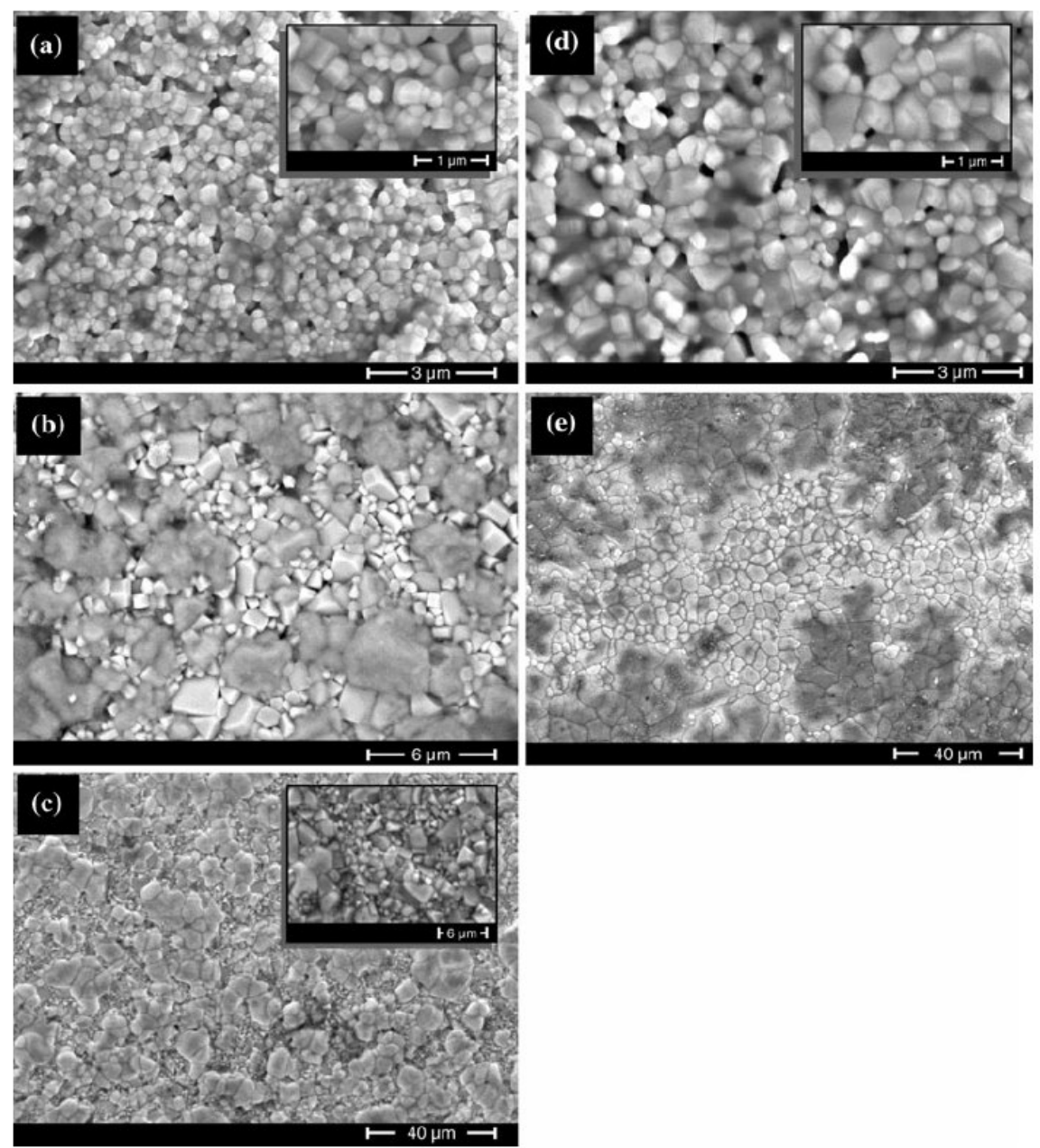

Fig. $6 \mathrm{SEM}$ images of the surface of ceramic bodies of 5 after various sintering treatments (heating rate $10{ }^{\circ} \mathrm{C} / \mathrm{min}$ ). a $1150{ }^{\circ} \mathrm{C}, 1 \mathrm{~h} ; \mathbf{b} 1250{ }^{\circ} \mathrm{C}$, $1 \mathrm{~h} ; \mathrm{c} 1300{ }^{\circ} \mathrm{C}, 1 \mathrm{~h} ; \mathrm{d} 1090{ }^{\circ} \mathrm{C}, 10 \mathrm{~h} ; \mathrm{e} 1150{ }^{\circ} \mathrm{C}, 10 \mathrm{~h}$ 


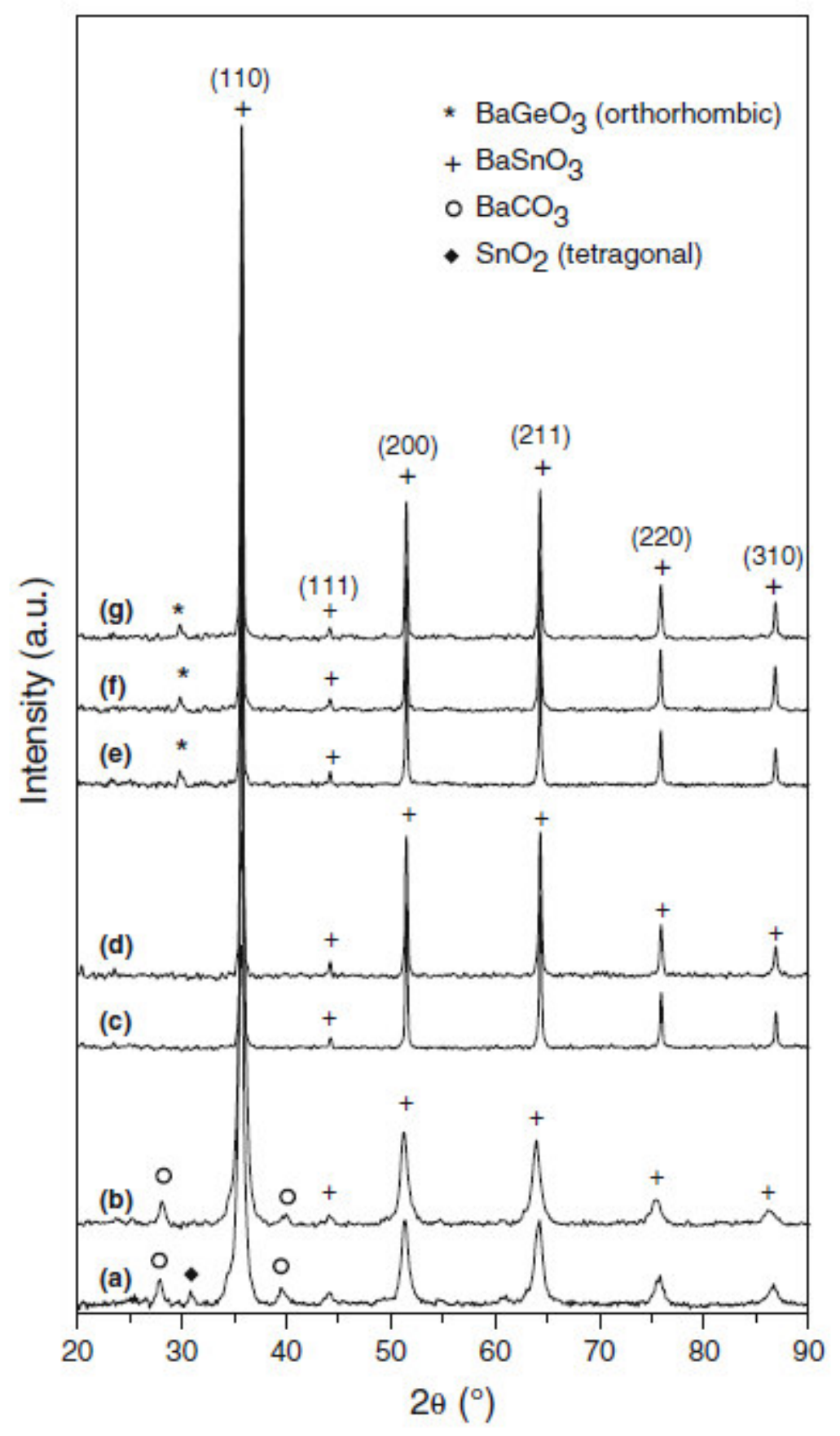

Fig. 7 Graphs (a) and (b) show the XRD patterns of the preceramic powders of precursor $\mathbf{1 5}(a)$ and $\mathbf{5}(b)$ resulting from a heating-rate controlled calcination process at $860{ }^{\circ} \mathrm{C}$ for $10 \mathrm{~h}(15)$ and $850{ }^{\circ} \mathrm{C}$ for $3 \mathrm{~h}(5)$, respectively. Graphs $(c-g)$ represent XRD patterns of ceramic bodies after various sintering procedures. Ceramic 5: (c) $1100{ }^{\circ} \mathrm{C}$, $10 \mathrm{~h} ;(d) 1300{ }^{\circ} \mathrm{C}, 1 \mathrm{~h}$. Ceramic $15:(e) 1150{ }^{\circ} \mathrm{C}, 10 \mathrm{~h} ;(f) 1250{ }^{\circ} \mathrm{C}$, $1 \mathrm{~h} ;(g) 1300{ }^{\circ} \mathrm{C}, 1 \mathrm{~h}$ 


\section{References}

[1] Souza IA, Cavalcante LS, Sczancoski JC, Moura F, Paiva-Santos CO, Varela JA, Simões AZ, Longo E (2009) J Alloys Compd 477: 877-882

[2] Shvartsman VV, Kleemann W, Dec J, Xu ZK, Lu SG (2006) J Appl Phys 99: 124111-pp.

[3] Müllert V, Beige H, Abicht H-P (2004) Appl Phys Lett 84: 1341-1343.

[4] Vivekanandan R, Kutty TRN (1990) Mater Sci Eng B 6: 221-231.

[5] Singh P, Brandenburg BJ, Sebastian CP, Singh P, Singh S, Kumar D, Parkash O (2008) Jpn J Appl Phys 47: 3540-3545.

[6] Movchikova A, Malyshkina O, Suchaneck G, Gerlach G, Steinhausen R, Langhammer HT, Pientschke C, Beige H (2008) J Electroceram 20: 43-46.

[7] Wang T, Chen XM, Zheng XH (2003) J Electroceram 11: 173-178.

[8] Kumar A, Singh BP, Choudhary RNP, Thakur AK (2005) Mater Lett 59: 1880-1888.

[9] Prokopalo OI (1976) Ferroelectrics 14: 683-685.

[10] Singh P, Kumar D, Parkash O (2005) J Appl Phys 97: 074103pp.

[11] Brauer H (1970) Z Angew Phys 29: 282-287.

[12] Wang X, Zhou F, Wang Z (2006) Dianzi Yuanjian Yu Cailiao 25: 44-46.

[13] Ostrick B, Fleischer M, Hampe U, Meixner H (1997) Sens Actuators B 44: 601-606.

[14] Tao S, Gao F, Liu X, Sørensen O T (2000) Sens Actuators B 71: 223-227.

[15] Chu X (2004) Mater Sci Eng B 106: 305-307.

[16] Hodjati S, Vaezzadeh K, Petit C, Pitchon V, Kiennemann A (2000) Catal Today 59: $323-334$.

[17] Upadhyay S, Kavitha P (2007) Mater Lett 61: 1912-1915. 
[18] Borse PH, Joshi UA, Ji SM, Jang JS, Lee JS, Jeong E.D, Kim HG (2007) Appl Phys Lett 90: 034103-1pp.

[19] Yuan Y, Lv v, Jiang X, Li Z, Yu T, Zou Z, Ye J (2007) Appl Phys Lett 91: 094107-1pp.

[20] Zhang Y, Zhang H, Wang Y, Zhang WF (2008) J Phys Chem C 112: 8553-8557.

[21] Larramona G, Gutierrez C, Pereira I, Nunes MR, da Costa F M A (1989) J Chem Soc Faraday Trans 85: 907-916.

[22] Kutty TRN, Vivekanadan R (1987) Mater Res Bull 22: 1457-1465.

[23] Lu W, Schmidt H (2005) J Eur Ceram Soc 25: 919-925.

[24] Cerda J, Arbiol J, Diaz R, Dezanneau G, Morante J.R (2002) Mater Lett 56: $131-136$.

[25] Udawatte CP, Yoshimura M (2001) Mater Lett 47: 7-10.

[26] Udawatte CP, Kakihana M, Yoshimura M (1998) Solid State Ionics 108: 23-30.

[27] Lu W, Schmidt H (2007) J Sol-Gel Sci Techn 42: 55-64.

[28] Song YJ, Kim S (2001) J Ind Eng Chem 7: 183-185.

[29] Jäger L, Lorenz V, Müller T, Abicht H-P, Rössel M, Görls H (2004) Z Anorg Allg Chem 630: 189-195.

[30] Köferstein R, Jäger L, Zenkner M, Ebbinghaus SG (2009) J Eur Ceram Soc 29: $2317-2324$

[31] Singh P, Kumar D, Parkash O (2005) J Mater Sci Mater Electron 16: 145-148.

[32] Upadhyay S, Parkash O, Kumar D (2001) J Mater Sci Mater Electron 12: 165-172.

[33] Wie X, Yao X (2007) Mater Sci Eng B 137: 184-188.

[34] Cernea M, Manea A, Piazza D, Galassi C, Vasile E (2007) J Am Ceram Soc 90: $1728-1732$. 
[35] Azad AM, Hon NC (1998) J Alloys Compd 270: 95-106.

[36] Tien L-C, Chou C-C, Tsai D-S (2000) Ceram Inter 26: 57-62.

[37] Upadhyay S, Parkash O, Kumar D (2001) Mater Lett 49: 251-255.

[38] Rice RW (1998) Porosity of Ceramics, ed. Marcel Dekker, New York, pp. 325 et seqq.

[39] Marković S, Mitrić M, Cvjetićanin N, Uskoković D (2006) Mater Sci Forum 518: $241-246$.

[40] Singh P, Parkash O, Kumar D (2005) Solid State Ionics 176: 2167-2170.

[41] He Z, Ma J, Zhang R (2004) Ceram Inter 30: 1353-1356.

[42] Iddles DM, Bell AJ, Moulson AJ (1992) J Mater Sci 27: 6303-6310.

[43] Köferstein R, Jäger L, Zenkner M, Abicht H-P (2008) J Mater Sci 43: 832-838.

[44] Völtzke D, Abicht H.-P (2000) Solid State Sci 2: 149-159.

[45] Kumar A, Choudhary RNP (2007) J Mater Sci 42: 2476-2485.

[46] Wang Z, Zhou F, Chen Z (2006) Dianzi Yuanjian Yu Cailiao 25: 58-60.

[47] Köferstein R, Jäger L, Zenkner M, Müller T, Ebbinghaus SG (2010) J Eur Ceram 30: $1419-1425$.

[48] Zenkner M, Jäger L, Köferstein R, Abicht H-P (2008) Solid State Sci 10: 1556-1562.

[49] Allred VD, Buxton SR, McBride JP (1957) J Phys Chem 61: 117-120.

[50] Program WinXPOW v1.06, Stoe \& Cie GmbH, Darmstadt (1999).

[51] Neff H (1959) Grundlagen und Anwendung der Röntgen-Feinstruktur-Analyse. R. Oldenbourg, München, p. 287 et seqq.

[52] Köferstein R, Abicht H-P, Woltersdorf J, Pippel E (2006) Thermochim Acta 441: $176-183$.

[53] Köferstein R, Jäger L, Zenkner M, Abicht H-P (2007) Thermochim Acta 457: $55-63$. 
[54] PDF 2 (International Centre for Diffraction Data, Pennsylvania) 2001, $\mathrm{BaSnO}_{3}$ [15780], $\mathrm{BaCO}_{3}$ [5-378], $\mathrm{SnO}_{2}$ [14-1445], $\mathrm{GeO}_{2}$ [83-546 hexagonal $_{\text {ing }}$ 73-1306 tetragonal $_{\text {, }} \mathrm{BaGeO}_{3}$ [37-137].

[55] Buscaglia MT, Bassoli M, Buscaglia V, Alessio R (2005) J Am Ceram Soc 88: 23742379.

[56] Garvie RC (1965) J Phys Chem 69: 1238-1243.

[57] Marks GW, Monson LA (1955) Ind Eng Chem 47: 1611-1620.

[58] Schatt W (1992) Sintervorgänge. VDI-Verlag, Düsseldorf, pp.78-100.

[59] Novikov II, Portnoj VK (1984) Superplastizität von Legierungen. Deutscher Verlag für Grundstoffindustrie, Leipzig, p.12 et seqq.

[60] Köferstein R, Jäger L, Zenkner M, Müller T, Abicht H-P (2008) Mater Chem Phys 112: $531-535$

[61] Geguzin YaE, Klinchuk YuI (1976) Poroshkovaya Metallurgiya 7: 17-25.

[62] Schatt W (1989) Z Metallkde 80: 809-816.

[63] Schatt W (1992) Solid State Phenomena 25-26: 23-28.

[64] Dror Y, Levi RD, Baltianski S, Tsur Y (2006) J Electrochem Soc 153: F137-F143. 